\title{
液晶光シャッタを用いた新しい照明装置
}

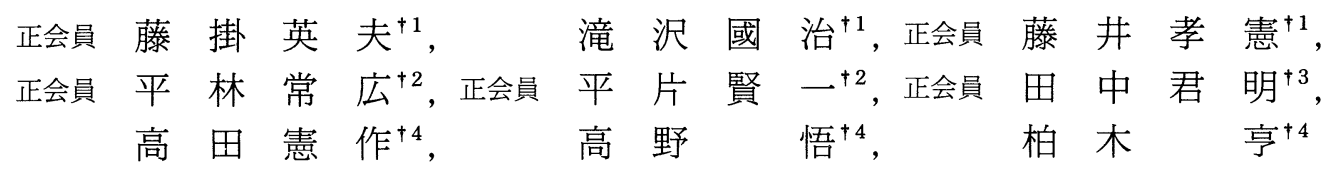

\section{Novel Luminaire Using a Liquid Crystal Light Shutter}

\author{
Hideo Fujikake ${ }^{\dagger 1}$, Kuniharu Takizawa ${ }^{\dagger 1}$, Takanori Fujii ${ }^{\dagger 1}$, Tsunehiro Hirabayashi ${ }^{\dagger 2}$, \\ Kenichi Hirakata ${ }^{\dagger 2}$, Yoshiaki Tanaka ${ }^{\dagger 3}$, Kensaku Takata ${ }^{\dagger 4}$, Satoshi Takano ${ }^{\dagger 4}$, \\ and Tohru Kashiwagi ${ }^{\dagger 4}$
}

\begin{abstract}
A compact luminaire consisting of a $270-\mathrm{W}$ metal halide lamp and a new light shutter using a composite film of liquid crystal and polymer, which can operate in the wide range from room temperature to more than $100^{\circ} \mathrm{C}$, has been developed for TV-lighting. The illuminance can be controlled approximately from 100 lux to 10000 lux by the voltage applied to the light shutter. The high-speed response ( $3 \mathrm{~ms})$ of the light shutter allows a stroboscopic lighting effect to be obtained by applying a pulsed voltage. A new lighting effect is also achieved by modulating the high-intensity light by electrical sound signal. This compact lighting system will be useful for various applications such as TV or movie locations, stages, and outdoor exhibitions.
\end{abstract}

\section{1. ま えがき}

映像撮影や舞台などの照明演出の高度化に伴い, 照 明装置の高機能化が望まれている．特にテレビ撮影で は，多様な番組演出に様々な照明効果が駆使されるた め, 高輝度照明装置の機能向上が急務とされている.

メタルハライドランプやキセノンランプなどの高出
力放電灯(数百 $\mathrm{W}$ 数 $\mathrm{kW}$ ) は, 高い発光効率と良好な 演色性を有し，ロケーション撮影やハイビジョン撮影 に好適であるが，次の課題を抱えている.

(1) 放電を維持するために, 放電電圧を大幅に変え ることができず，光量の制御が困難である.

(2) 点灯直後の輝度や色温度が安定せず, しかも消 灯後の再点灯に時間を要するなど, 操作性や運用

キーワード : 照明装置, 液晶光シャッタ, 液晶・高分子複合膜

1993 年 1 月 21 日受付, 1993 年 6 月 3 日再受付

$\dagger 1$ NHK 放送技術研究所 ( 1157 東京都世田谷区砧 1-10-11, TEL 03-5494-2396)

$\dagger 2$ NHK 放送技術局 ( 150 150 - 1 東京都渋谷区神南 2-2-1, TEL 03-5478-4760)

$\dagger 3$ NHK 技術局 (T 150-01 東京都渋谷区神南 2-2-1, TEL 03-5478-5307)

$\dagger 4$ 住友電気工業株式会社 大阪研究所 ( $\bar{T} 554$ 大阪市此花区島屋 1-1-3, TEL 06-466-5637)

$\dagger 1$ NHK Science \& Technical Research Laboratories(1-10-11, Kınuta, Setagaya Ku, Tokyo 157, Japan)

$\dagger 2$ NHK Broadcast Engineerıng Department (2-2-1, Jınnan, Shıbuya Ku, Tokyo 150-01, Japan)

$\dagger 3$ NHK Engineerıng Adminıstratıon Department (2-2-1, Jinnan, Shıbuya Ku, Tokyo 150-01, Japan)

$\dagger 4$ Osaka Research Laboratories, Sumitomo Electric Industries, Ltd (1-3, Shımaya 1-chome, Konohana Ku, Osaka 554, Japan) 
性が劣る。

そのため, 放電灯の光制御には発光源の輝度を制御 するのではなく，金属性のブラインドまたはアパーチ ヤを用いて光束を制限する方式が採用されている．し かし，こうした機械式光シャッ夕は, 動作速度が遅 い, 動作音が発生する, 簡便性が劣るなどの難点を有 し, その用途は極めて限られている. そのため, 高輝 度放電灯を活用するには，強力な照明光を自在に制御 できる新しい光シャッタが必要とされる。

一方，ディスプレイとして発展してきた液晶素子 は，低電圧で透過光を制御できる利点をもつが，従来 の TN 液晶素子(Twisted Nematic Liquid Crystal) は, 次の問題を有している.

(1) 偏光板が必要なため, 無偏波光に対して透過率 が低い（35\%以下）.

(2) 偏光板が光を吸収して発熱・劣化するため, 高 輝度な光を制御できない.

（3）大面積の光シャッ夕の製作が困難である.

それに対して, 近年開発された液晶・高分子複合 膜 ${ }^{1) ~ 3)}$ (Composite Film of Liquid Crystal and Polymer)は, 固相の高分子中にネマティック液晶を保持 し, 光散乱効果により無偏波光を強度変調する機能を もつため, 透過率が高い, 耐光性が高い, 大面積化が 容易などの特長を有する. そのため, 現在, 投写型デ イスプレイなどへの応用が期待されている4) 6).

我々はその優れた耐光性に着目し, 液晶・高分子複 合膜を用いた照明装置を考案し, 開発を進めている. この照明装置を実現するには，従来の素子7)に比べて 耐熱性が高く, 高温の灯体内に組み込める液晶・高分 子複合膜が必要である。そこで，我々はマネティッ ク・アイソトロピック相転移温度が極めて高い液晶材 料と耐熱樹脂を用いることにより， $100^{\circ} \mathrm{C}$ 以上の高温 でも安定に動作する液晶光シャッ夕を開発した ${ }^{8)}$.さ らに, この液晶光シャッタと $270 \mathrm{~W}$ の高輝度メ夕ル 八ライドランプを一体化することにより, 被写体照度 を高速かつ広範囲に制御できるコンパクトな照明装置 を初めて試作した9).

本論文では, 液晶光シャッタを用いた新しい照明装 置の動作原理および基本特性を詳述すると共に，スト ロボ照明効果, 音声による光強度の連動など, 高速性 を生かした特殊効果照明や, 散乱光を用いた照明効果 について述べる。

\section{2. 液晶光シャッタ}

\section{1 構成と動作原理}

液晶光シャッ夕は, 図 1 ( a ) に示すように, 海綿状 $1530(108)$
(もしくは小滴状)のネマティック液晶を含有する高分 子膜 (16 $\mu \mathrm{m}$ 厚) と, 透明電極 $\mathrm{ITO}\left(\mathrm{In}_{2} \mathrm{O}_{3}: \mathrm{Sn}\right)$ が付着 した 2 枚のガラス基板で構成される.

液晶光シャッ夕の動作原理は, 以下に示す通りであ る. 図 1(a) に示すように, ITO 間に電圧が印加され ていない場合，液晶分子の配列方向(配向)は，高分子 界面からの規制力を受けて不規則である. 光シャッ夕 に入射した光は，液晶と高分子の屈折率の不整合や， 配向の屈曲・不連続により, 複合膜内で強く散乱され る.この時, 液晶光シャッ夕は最ガラスのように白濁 し，不透明である(オフ状態)。

一方，図 1(b) に示すように，充分大きな交流電圧 が液晶光シャッ夕に印加された場合, 正の誘電率異方 性 $\Delta \varepsilon$ （＝分子軸に平行な方向の比誘電率 $\varepsilon_{/ /}$一垂直な 方向の比誘電率 $\left.\varepsilon_{\perp}\right)$ をもつ液晶分子は, 電界に平行に 再配列し，ホメオトロピック配向を形成する。あらか じめ, 液晶の常光屈折率 $n_{0}$ を, 高分子の屈折率 $n_{P}$ に近似してあるため屈折率の不整合が解消し，入射光 はそのまま透過して直進光となる。この時, 液晶光シ ヤッ夕は透明に変化する (オン状態).

上記の光変調動作を得るためには, 液晶の常光届折 率 $n_{o}$, 異常光屈折率 $n_{e}$ および高分子の屈折率 $n_{P}$ を，以下の式を満足するように定めなければならな い.

$$
n_{P} \simeq n_{o}<n_{e}
$$

この場合, 使用される液晶の屈折率異方性 $\Delta n\left(=n_{e}\right.$ 一no)が大きいほど強い光散乱効果が得られる。

\section{2 液晶光シャッ夕の作製}

液晶光シャッ夕の作製においては，大面積化に有利 な溶媒蒸発法 ${ }^{3}$ を適用した。実際的な作製方法は次の 通りである。最初に，図 2 に示すように高分子とネマ ティック液晶を, 共通の溶媒に溶解した後, スピンコ 一ト法またはバーコート法により, ITO 膜上に塗布 する，次に，溶媒を蒸発させることにより，ネマティ

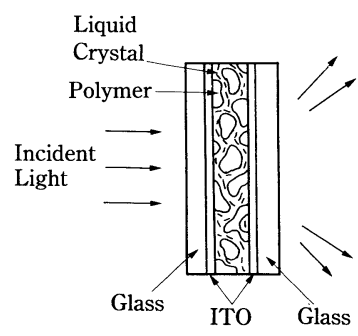

(a) Off State

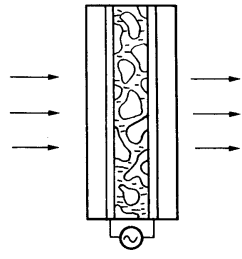

(b) On State
図 1 液晶光シャッ夕の動作原理 Operating principle of the liquid crystal light shutter. 
ック液晶を折出・凝集させる. その結果として, 液晶 と高分子は相分離状態になる.

この際, 液晶含有率を高くすることにより, 複雑な 海綿状の高分子を生成することができる．その結果， 乱れた液晶配向が誘発され, 液晶内部の光散乱も効果 的に利用することが可能になる.しかし, 液晶含有率 が高過ぎると複合膜が柔軟になり, 均一な塗布が困難 になる.ここでは, 光散乱効果と成膜の均一性を考慮 し, 液晶と高分子の重量配合比を $7: 3$ に定めた。

なお, 強い光散乱効果を得るためには, 液晶分散体 の大きさを波長オーダーに制御しなければならない. 本方式では, 溶媒の蒸発速度を変えることにより分散 体の大きさを制御することができる，例えば，基板を 加熱した場合，微細な液晶分散体が生成される。すな わち, 基板温度の制御により分散構造を最適化し, 高 い消光比を得ることが可能である.

最後に，もう一方のガラス基板を圧着する. 本方式 では， 2 枚の基板が固相の高分子により支持されるた め, 液晶光シャッ夕の大面積化が極めて容易である. また，このような方法で生成される液晶・高分子複合 膜は, 光重合相分離法 ${ }^{10)}$ で不可欠な光重合開始剂を 含まないため, 可視光照射に対して化学的に安定であ り, 紫外線による劣化も比較的少ない.

ここでは, 液晶光シャッタの耐熱性を向上するため に, ネマティック・アイソトロピック相転移温度 $\left(157^{\circ} \mathrm{C}\right)$ が極めて高い多環系ネマティック液晶(主成分 はシアノターフェニル系化合物 $\left.{ }^{11}\right)$ を採用した。なお， この多環系液晶は, 分子量が大きくオーダーパラメー 夕11) が高いため, 屈折率異方性 $\Delta n\left(n_{o}=1.521, n_{e}=\right.$ 1.773) や誘電率異方性 $\Delta \varepsilon\left(\varepsilon_{\perp}=4.2, \varepsilon_{/ /}=16.7\right)$ が大きい という利点も有する. 一方, 本素子の透明高分子とし

(a) ITO Coating

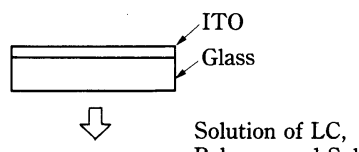

(b) Solution Coating

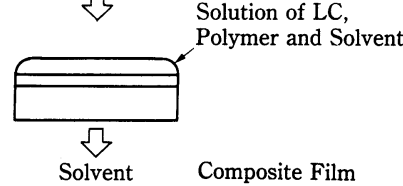

(c) Solvent Evaporation

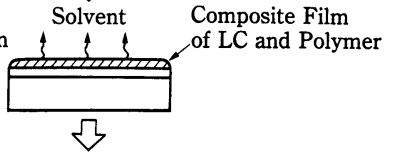

(d) Press

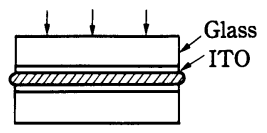

図 2 液晶光シャッ夕の作製

Fabrication of the liquid crystal light shutter.

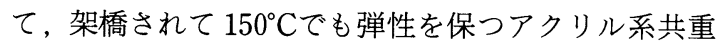
合体（屈折率 $n_{P}=1.48$, 比誘電率 7.5) を用いた.

\section{3 電気光学特性}

高輝度な照明光を変調するには, 可視光の吸収に伴 う発熱を防止し, 耐光性を向上させることが最も重要 である，液晶・高分子複合膜では偏光板が不要なため, 可視全域の無偏波光に対する最大透過率が TN 液晶 素子の約 $35 \%$ に比べて大幅に改善する.

液晶光シャッ夕の動作を把握するために, 最初に透 過率の波長依存性を測定した。ここでは, 波長入が $457.9 \mathrm{~nm}$ の Arレーザ, $514.5 \mathrm{~nm}$ の Arレーザ, およ び $632.8 \mathrm{~nm}$ の $\mathrm{He}-\mathrm{Ne} レ ー サ ゙ か ら の$ 単色平行光を, それぞれ液晶光シャッ夕に入射し, 散乱角 $\theta$ (光軸と 散乱光のなす角度）が $3^{\circ}$ 以内の光を透過光として識 別・検出した.すなわち, 図 3 に示すように, レンズ とアパーチャからなるシュリーレン光学系により, $6^{\circ}$ の受光角 $(=2 \theta)$ を設けて, 液晶光シャッ夕からの光 強度を実測した。

図 4 は, 室温の液晶光シャッ夕に交流電圧（周波数 $1 \mathrm{kHz}$ の矩形波）を印加した場合の透過率である. 同

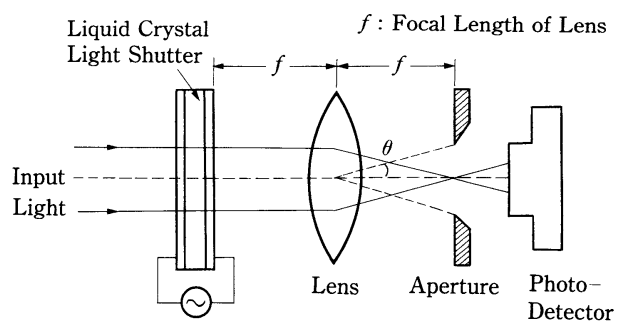

図 3 液晶光シャッ夕の光変調特性の測定光学系 Optical system for measurements of electro-optic property of the liquid crystal light shutter.

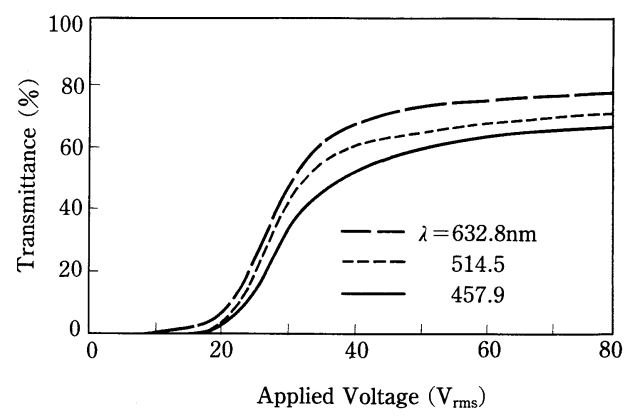

図 4 様々な波長における液晶光シャッ夕の透過率の 印加電圧依存性

Dependence of transmittance of the liquid crystal light shutter on applied voltage for lights of different wavelength. 
罒では, 長波長光の透過率が短波長光に比べて高く, 若干の波長依存性が生じている.これは, 長波長光が 微小な液晶分散体による散乱を受けにくいためと考え られる。しかし，いずれの波長においても，700：1 以上の高い消光比 $(=$ オン状態の透過率 : オフ状態の 透過率）と, $65 \%$ 以上の最大透過率（オン状態の透過 率）が得られている. 測定された透過率には, ガラス 基板や ITO 透明電極での反射損失が含まれるため, 基板を無反射処理することにより,さらに最大透過率 を高めることも可能である。

なお, 最適な受光角は光散乱効果に依存し, 複合膜

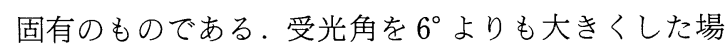
合, 最大透過率はほぼ一定で, オフ状態の透過率が増 大する.一方, $6^{\circ}$ より 小さくすると, 最大透過率 が減少する。したがって, 本素子を用いて高消光比を 得るには, $6^{\circ}$ の受光角が最適といえる.

図 5 は, $\mathrm{Xe}$ ランプからの白色平行光（波長は $400 \sim 690 \mathrm{~nm}$ ) を用いて, 電気光学特性を測定した結

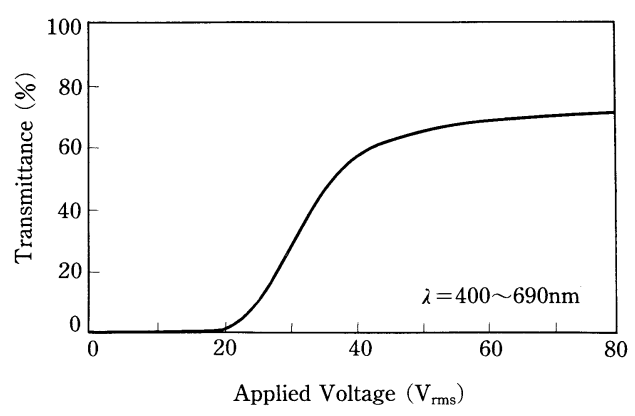

図 5 白色光に対する液晶光シャッタの透過率の印加 電圧依存性

Dependence of transmittance of the liquid crystal light shutter on applied voltage for white light.

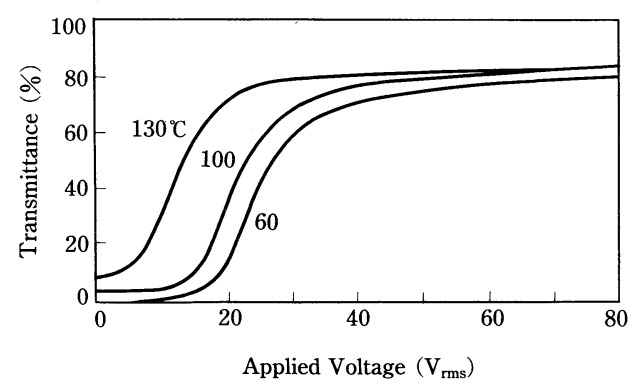

図 6 様々な温度における液晶光シャッタの透過率の 印加電圧依存性

Dependence of transmittance of the liquid crystal light shutter on applied voltage for several operation temperatures.
果である.同図では, $70 \%$ 超える最大透過率と, 500：1の消光比が達成されている。なお，本実験に おいて, 中間調の透過光が赤色化し, 色温度が低下す る現象が認められた。これは, 中間調において短波長 光の透過率が, 長波長光に比べて相対的に低下するた めである (図 4 参照)。この色温度変化を改善するに は, 分散構造や駆動方法の検討を含めた議論が必要と 考えられる。

実際の高出力放電灯からの照明光には, 可視光以外 に赤外線 (特に近赤外線) や紫外線が多く含まれ, それ らを基板や複合膜が吸収するため, 液晶光シャッ夕自 身が発熱する.さらに, 高温の灯体からの熱伝導で加 熱されるため, 液晶光シャッ夕には耐熱性が必要とさ れる。

図 6 は, 電気ヒータで加熱した液晶光シャッタに, $\mathrm{Xe}$ ランプからの単色光 (中心波長 $600 \mathrm{~nm}$ ) を入射した 場合の電気光学特性である. 同図では, $130^{\circ} \mathrm{C}$ 高温 環境でも光変調動作が可能であることが示されてい る.なお, 高温では液晶の粘度や弾性定数が減少する ため, 液晶光シャッ夕の閾值電圧が低下する。さら に, 温度上昇と共にオフ状態の透過率が増加するた め, 消光比が低下する.これは液晶分子の熱運動によ り, 液晶のオーダーパラメータが減少し, 光散乱に寄 与する屈折率異方性が低下するためと考えられる.

上記のように高温環境では消光比が低下するため, 動作温度を考慮した素子設計が必要である。すなわ ち, 動作温度の増加に応じて複合膜を厚膜化し, 光散 乱効果を高めなければならない.なお, 経時変化につ いては, $100^{\circ} \mathrm{C}, 500$ 時間の耐熱試験後も, 特性劣化 が認められておらず, 実用的な高温耐久性が確保され ている.

液晶・高分子複合膜では, ネマティック液晶が狭い

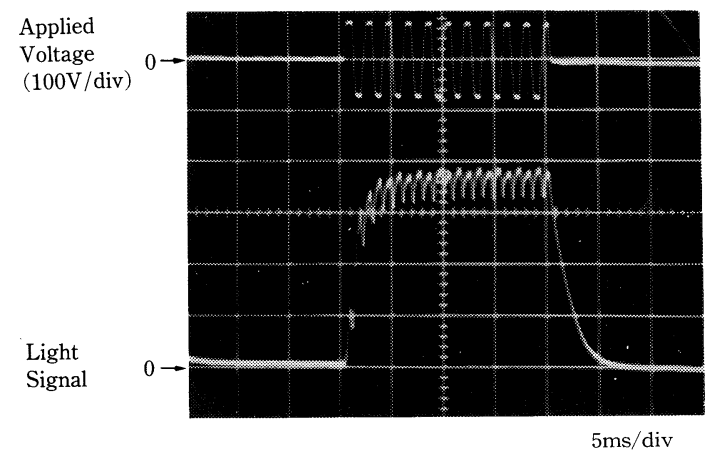

写真 1 液晶光シャッタの電圧パルス応答 Electro-optic response of the liquid crystal light shutter to applied voltage pulse.

テレビジョン学会誌 Vol. 47, No. 11 (1993) 
領域に封じ込められて, 高分子界面からのアンカリン グ効果 ${ }^{12)}$ が大きいため, 高速な立下がり動作が得ら れる. 写真 1 は, 交流電圧 $(70 \mathrm{~V} \mathrm{rms}$, 周波数 500 $\mathrm{Hz}$ ) のパルスを液晶光シャッタに印加し, 室温での応 答時間を測定した結果である. 立上がり時間（透過率 0\%〜90\%)，および立下がり時間(100\%～10\%）は共 に $3 \mathrm{~ms}$ であり, TN 液晶素子の約 10 倍の高速応答が 得られている。なお, 液晶光シャッ夕が加熱された場 合, 液晶の粘度が減少するため, さらに高速な光変調 動作が期待できる。

\section{3. 液晶照明装置}

\section{1 灯体の構成}

高い耐熱性をもつ液晶光シャッ夕の実現により, 灯 体温度が $100^{\circ} \mathrm{C}$ 以上に達する照明装置との一体化が初 めて可能になった，ただし，本方式では光散乱効果を 利用するため, 以下に示すような光学的な配慮が必要 である。

高い消光比を得るには, 液晶光シャッ夕に平行光を 垂直入射することが望ましい(図 3 参照)。しかし, 実 際に液晶光シャッ夕を照明光源に組み込む場合, 様久 な角度の光が液晶光シャッ夕に入射する. その際, 散 乱光により消光比が低下するが, 液晶・高分子複合膜 は，従来の $\mathrm{TN}$ 液晶に比べ広い視角特性 ${ }^{13)}$ をつた め, 実用的な消光比を確保することが可能である.

ただしその場合, フレネルレンズを用いて, 光源か らの放射光をコリメートする必要がある.さらに, 反 射鏡を組合せて, 後方への光も平行光として前方に放 射し, 液晶光シャッ夕の性能を充分に引き出すことが 重要である.

我々は, 実際の照明灯体に組込むために, 大型の液 晶光シャッタ（写真 2 参照, 有効口径 $200 \mathrm{~mm}$ ) を作製 した。さらに上記の光学的な設計指針を考慮し, 図 7 に示すように，メタルハライドランプ $(270 \mathrm{~W}$ ，オス ラム社)を用いたスポットライト(ザハトラー社ディレ クター $270 \mathrm{D}$, 照度半值角は $6^{\circ}$ ) と, 液晶光シャッタ を一体化することにより, 光制御機能を有する液晶照 明装置(写真 3 参照)を試作した。

ここでは, 装置をコンパクト化するために, 液晶光 シャッタをフレネルレンズ (口径 $130 \mathrm{~mm}$ ) に可能な限 り近づけ（光シャッタとレンズの距離は $60 \mathrm{~mm}$ ), そ の間に赤外線と紫外線を除去する光学フィル夕（口径 $150 \mathrm{~mm}$ ）を插入した。

この光学フィルタは, 誘電体多層膜が両面に積層さ れた 3 枚の耐熱ガラス（テンパックス）で構成され， 図 8 に示すように, 可視光に対して高い透過率（約

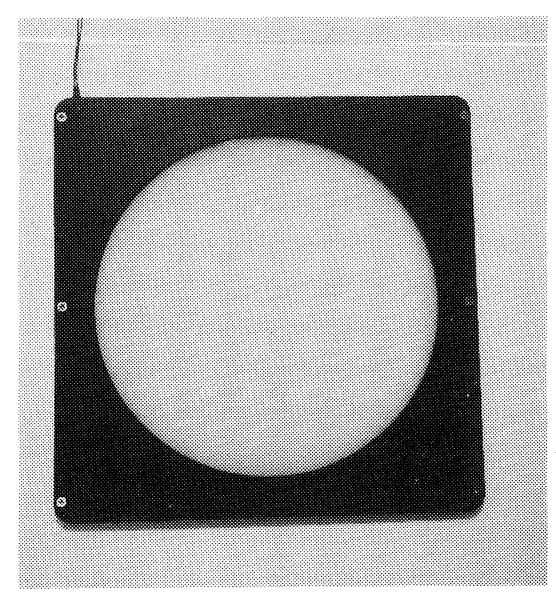

写真 2 液晶光シャッ夕の外観

Appearance of the liquid crystal light shutter.

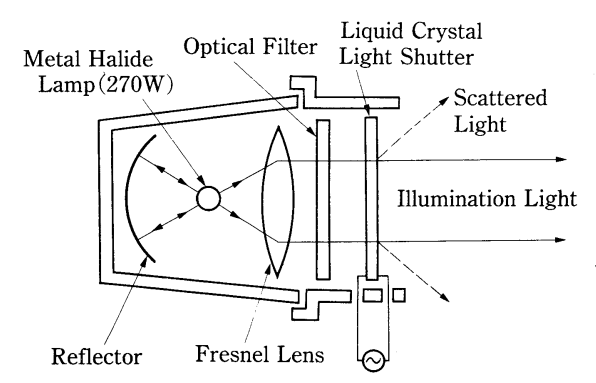

図 7 照明装置の構造

Schematic diagran of the liquid crystal luminaire.

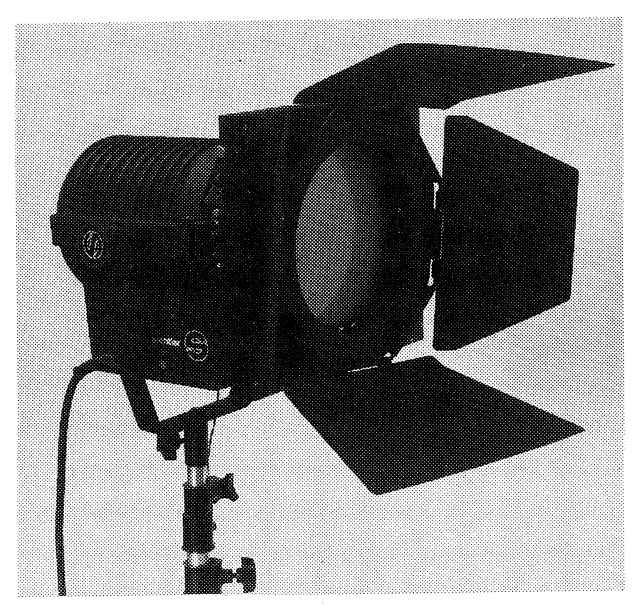

写真 3 液晶照明装置の外観

Appearance of the liquid crystal luminaire.

$80 \%$ ）を有すると共に，大部分の不可視光を反射・除 去する.また, 光学フィル夕は灯体からの対流による 熱伝導を遮断し, 液晶光シャッタを保護する役割を担 


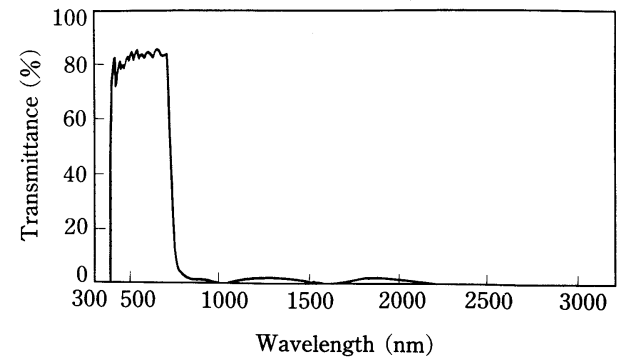

図 8 光学フィルタの透過分光特性

Transmission spectra of the optical filter.

うため， $200^{\circ} \mathrm{C}$ 以上の耐熱性を備えている。なお，液 晶光シャッ夕と光学フィル夕を支持する灯体には, 多 数の小穴により放熱設計が施されている.

このフィルタの最も大きな特徵は, 広帯域に及ぶ赤 外線の除去能力にあり, それにより液晶光シャッ夕の 温度上昇を大幅に軽減することが可能である.今回, 照明装置の連続点灯試験 (気温は $25^{\circ} \mathrm{C}$ 程度)において, 液晶光シャッ夕の表面温度を $50^{\circ} \mathrm{C}$ に留めることがで きた。したがって, さらに高出力で実用的な $1 \mathrm{~kW}$ 以 上の放電灯に適用することも可能と考えられる.

なお，本装置では光源としてデイライト用放電灯 （スペクトルが太陽光に近く, 色温度は約 $5600 \mathrm{~K}$ ）を 採用しているため, 屋外光を取り入れた撮影(例えば, オープンスタジオ，エントランスホール）にも使用可 能であり，幅広い用途が考えられる。

\section{2 基本動作}

試作した液晶照明装置は, 液晶光シャッタと灯体が コンパクトに一体化されているため, 通常の照明器具 と同様に取扱うことが可能である.

本装置の基本的な動作特性を評価するために, 照射 光軸上の照度を測定した. 図 9 に液晶光シャッタへの 印加電圧と照度の関係を示す. 印加電圧を変えること により，2 mの距離における照度を $100 \mathrm{~lx}$ から $10000 \mathrm{~lx}$ まで, 広範囲かつ連続的に制御できること がわかる.また, 測定距離を変えても, 同様に高い消 光比が得られることから, 本照明装置はテレビ撮影で 最低限必要とされる $30: 1$ の消光比を充分に満足し, 高い実用性を有していることがわかる。なお，300時 間以上の点灯試験後も, 光変調特性の劣化は認められ ておらず，長時間の安定動作が期待できる．

液晶照明装置では, 光散乱効果を利用して照度を制 御するため, 液晶光シャッタの動作状態により配光特 性が異なる，そのため, 多数の液晶照明装置を局所照 明（スポットライトなど）として同時に使用する場合, 大きく広がる散乱光により，互いの消光比が低下する

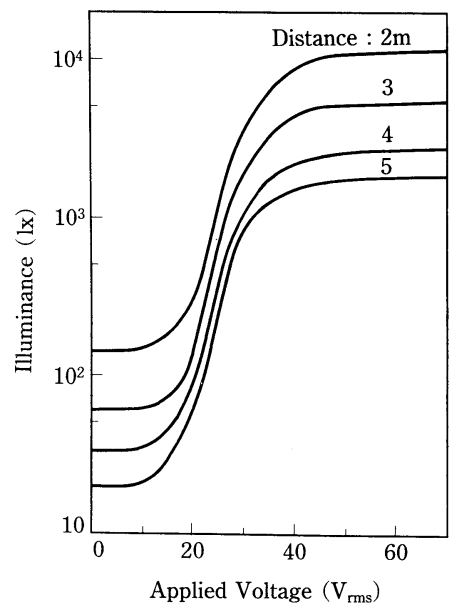

図 9 液晶照明装置の照度の印加電圧依存性 Dependence of illuminance from the liquid crystal luminaire on applied voltage.

可能性がある. 今後, 散乱光を適度に制御できるアパ 一チャを設けるなど, 光学系の改良が必要と考えられ る.

\section{3 照明効果への応用}

ハロゲンランプ(白熱灯)の輝度を制御する調光シス テムは, 現在のスタジオ照明の主流をなすが, 応答が 遅く, 高速性を要する照明演出に適さない。 また, 機 械式光シャッ夕も動作速度に難点を抱える。 それに対 して液晶照明装置は, 高速動作を特徵とし, 様々な照 明演出に有効である.

ここでは, ストロボ照明効果を得るために, 液晶光 シャッタに周期的な交流電圧パルスを印加し, 間欠的 なフラッシュライトを実現した. 写真 4(a)，（b ) お よび(c)は, 周期 $T$ がそれぞれ $350 \mathrm{~ms}, 200 \mathrm{~ms}$ お よび $100 \mathrm{~ms}$ の交流電圧パルス（振幅 $80 \mathrm{~V}_{\mathrm{rms}}, 10 \mathrm{~ms}$ 幅, 周波数 $1 \mathrm{kHz}$ の矩形波) を液晶光シャッ夕に印加 し, 左から右に移動する 1 つの被写体 (人形)を多重撮 影した結果である．ブレが少なく高コントラストなス トロボ映像が得られていることがわかる．このような ストロボ照明効果は，動体の観測実験だけでなく， 様々な番組での特殊効果にも応用が可能である.

また, 液晶光シャッ夕はミリ秒単位の高速応答をも つため, 音声信号による照明光の変調が可能である. ここでは, 図 10 に示すような駆動装置を構成するこ とにより, 音と光の連動装置を試作した。同装置て は, マイクまたは音声テープ再生機(効果音)からの音 声電気信号が, 電圧増幅された後, 液晶光シャッ夕に 直接印加される. 動作例として, 人の発声音を入力し た場合の光強度の変化を写真 $\mathbf{5}$ に示す. 交流の音声信 


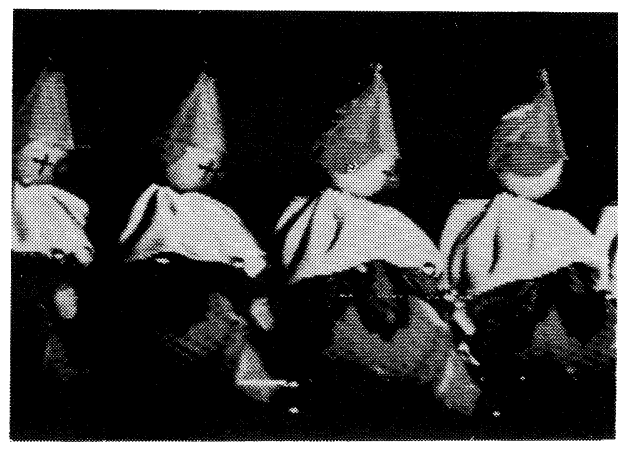

(a) $T=350 \mathrm{~ms}$

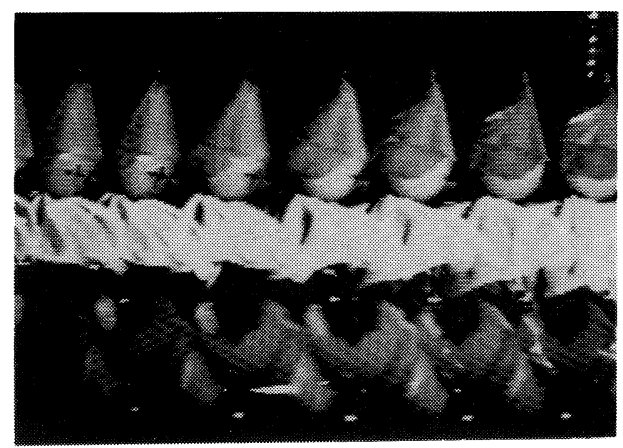

(b) $T=200 \mathrm{~ms}$

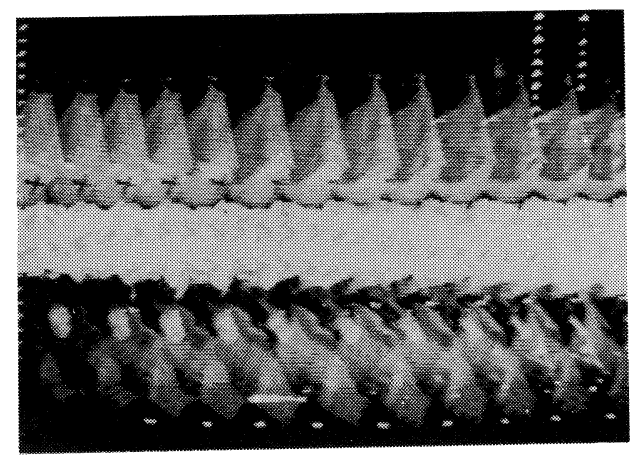

(c) $T=100 \mathrm{~ms}$

写真 4 液晶照明装置を用いたストロボ照明効果 Stroboscopic lighting effect with the liquid crystal luminaire.

号により, 光強度が変調されていることがわかる

このような音声と照明光の連動効果は, 雷鳴などの 効果音に合わせて雷光をりアルに演出したり, 電車な どの移動体の通過を照明効果で表現するシーンの撮影 に有効である。また, 音楽番組などで楽器音に合わせ て, セットの一部または背景の明るさや色を瞬時に変 える新しい照明演出にも応用可能である。

液晶照明装置は, 光シャッタがオン状態の場合, ス ポットライト本体の機能を発揮する.一方，オフ状態 では, 液晶光シャッタが 2 次的な面光源として働き, フラッドライトと同等の配光状態を示す.したがっ

論 文 $\square$ 液晶光シャッタを用いた新しい照明装置

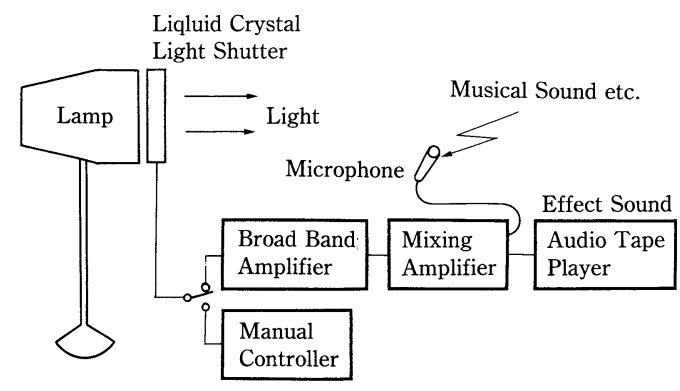

図 10 音声信号に同期して動作する液晶照明装置の 構成

Block diagram of the liquid crystal luminaire operating syncronously with sound signal.

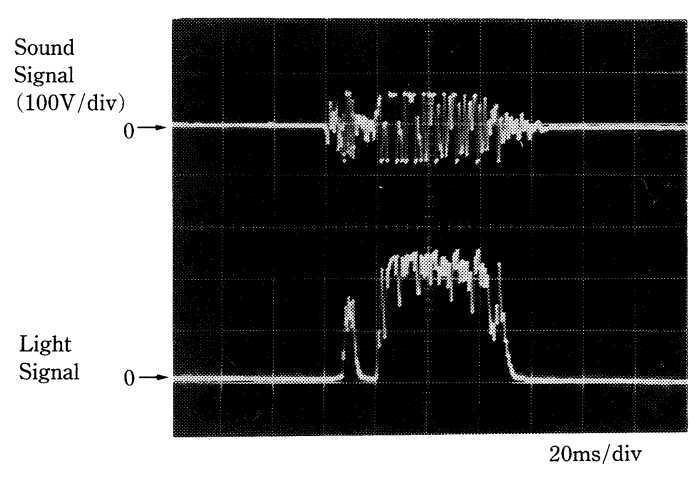

写真 5 音声信号駆動による液晶照明装置の光強度変化 Electro-optic response of the liquid crystal luminaire to the sound signal.

て, 大面積の液晶光シャッタを用いれば, 1 台の液晶 照明装置を多目的に使用することが可能である．その ため, 液晶照明装置は特にロケーション機材の簡素化 に効果的である。

また, 液晶照明装置を用いれば, 散乱光強度を連続 的に制御できるため, 影の柔らかさを自在に変えるこ とができる.それにより, 被写体の質感や人物の表情 を繊細かつ動的に演出することも可能となろう．今 後, 液晶照明装置は散乱光を積極的に用いる照明演出 においても, 重要な役割を担うものと考えられる.

\section{4.むす び}

高速, 高消光比で耐熱性を有する液晶光シャッ夕を 灯体内に組み込むことにより, 光制御機能を有する高 輝度照明装置を開発し, その応用例としてストロボ照 明効果や, 音と光の連動効果を実現した. 液晶光シャ ッ夕は, その優れた機能性と操作性から, 高輝度光源 としての放電灯の用途を飛躍的に広げる可能性があ る。すなわち, 本照明装置はテレビ撮影に限らず，映 
画・写真などの撮影照明, 演劇やホールなどの舞台照 明, 野外の建造物のライトアップなど, 広範囲な分野 に応用が可能である。

今後, さらに機能性を高めるため, アパーチャを用 いて配光特性の制御を図ると共に, 光源を大型化する 予定である.なお, 今回の液晶光シャッ夕には, 中間 調で色温度が変動する問題がある. 色温度の課題 ${ }^{14)}$ についても，改善の方策を検討したい。

\section{〔参 考 文 献〕}

1) J. L. Fergason: "Polymer Encapsulated Nematic Liquid Crystals for Display and Light Control Applications", Proc. SID., 16, pp. 68-70 (May 1985)

2) J. W. Doane, N. A. Vaz, B. G. Wu and S. Zumer: "Field Controlled Light Scattering from Nematic Microdroplets", Appl. Phys. Lett., 48, 4, pp. 269-271 (1986)

3) T. Kajiyama, A. Miyamoto, H. Kikuchi and Y. Morimura: "Aggregation States and Electro-Optical Properties Based on Light Scattering of Polymer/(Liquid Crystal) Composite Films", Chem. Lett., 1989, pp. 813-816 (1989)

4) K. Takizawa, H. Kikuchi, H. Fujikake and M. Okada: "Transmission Mode Spatial Light Modulator Using a $\mathrm{Bi}_{12} \mathrm{SiO}_{20}$ Crystal and Polymer-Dispersed Liquid-Crystal Layers", Appl. Phys. Lett., 56, 11, pp. 999-1001 (Mar. 1990)

5) K. Takizawa, H. Kikuchi, H. Fujikake and M. Okada : "Polymer-Dispersed Liquid-Crystal Light Valves for Projection Displays", Proc. SID, 22, pp. 250-253 (May 1991)

6) M. Kunigita, Y. Hirai, Y. Ooi, S. Niiyama, T. Asakawa, K. Masumo, H. Kumai, M. Yuki and T. Gunjima: "A Full-Color Projection TV Using LC/Polymer Composite Light Valves", Proc. SID, 21, pp. 227-230 (May 1990)

7) N. A. Vaz, G. W. Smith, G. P. Montgomery, Jr.: "Polymer-Dispersed Liquid Crystal Films Formed by E-Beam Cure", SPIE, 1257, pp. 9-16 (1990)

8）藤掛, 滝沢, 藤井, 高田, 高野, 柏木, 平林, 平片, 田中 : “高輝度 照明用の高耐熱性液晶変調素子”, 第 40 回応物春季予稿集, 29pZK12 (Mar. 1993)

9）田中, 平林, 平片, 滝沢, 藤掛, 藤井, 高田, 高野, 柏木 : “液晶光 シャッタを用いた TV 照明装置”, テレビ学会放送現業研資, BFO93-3, 13 (Jan. 1993)

10) N. A. Vaz, G. W. Smith and G. P. Montgomery, Jr: "A Light Control Film Composed of Liquid Crystal Droplets Dispersed in a UV-Curable Polymer", Liq. Cryst., 146, pp. 1-15 (1987)

11) D. Coater, S. Greenfield, I. C. Sage, G. Smith: "Liquid Crystal Mixtures for Polymer Matrix Displays", SPIE, 1257, pp. 37-45 (1990)

12) B. G. Wu, J. H. Erdmann and J. W. Doane: "Response Times and Voltages for PDLC Light Shutters", Liquid Crystals, 5, 5, pp. 1453-1465 (1989)

13) B. G. Wu, J. L. West and J. W. Doane: "Angular Discrimination of Light Transmission through PolymerDispersed Liquid-Crystal Films", J. Appl. Phys., 62, 9, pp. 3925-3931 (Nov. 1989)

14）藤井, 滝沢, 藤掛, 高田, 高野, 柏木, 平林, 平片, 田中, 北, 田村, 浅川: “照明用液晶光変調素子の色温度特性”, 第 40 回応物 春季予稿集, 29pZK13 (Mar. 1993)

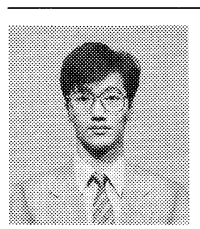

藤掛 英夫势 昭和 60 年, 東北大学大学院 工学研究科修士課程修了. 同年, NHK に入 局. 同長野放送局を経て, 昭和 63 年, 同放 送技術研究所に勤務. 以来, 液晶光変調素 子, 光書込み型空間光変調素子, 投写型ディ スプレイの研究に従事. 現在, 同所先端素子 研究部に所属. 正会員.

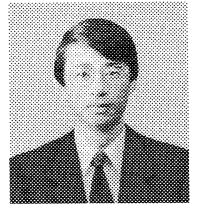

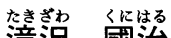

滝沢 國治 昭和 43 年, 東北大学工学部 電子工学科卒業. 同年, NHK に入局. 同技 術運用部を経て, 昭和 49 年より，同放送科 学基礎研究所物性研究部に勤務. 以来, 導波 路形光デバイス, 空間光変調素子などの研究 に従事. 現在，同放送技術研究所先端素子研 究部主任研究員. 工学博士.

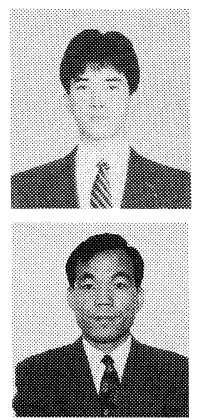

藤并焦孝憲 平成元年, 熊本大学大学院工 学研究科情報工学専攻修士課程修了. 同年, NHK に入局. 熊本放送局を経て，平成 4 年 より, 同放送技術研究所に勤務。以来, 液晶 光変調素子の研究に従事. 現在, 同所先端素 子研究部に所属. 正会員.

楼林管広昭和 44 年, NHK 亿入局. 昭和 50 年, 工学院大学電気工学科卒業. 本 部にて番組制作技術に従事. 昭和 51 年より, 松山放送局にて番組制作，昭和 57 年より 再び本部制作技術にてドラマを中心に照明を 担当しつつ各種現場設備の開発に従事. 正会 員.

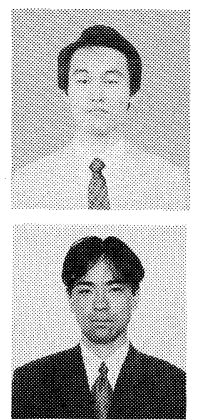

半片 师賢一昭和 62 年, 千代田工科芸術 専門学校電子通信研究科卒業. 同年, NHK に入局. 同放送技術研究所を経て, 平成 3 年 より，同放送技術局制作技術センター映像技 術に勤務し, 液晶光シャッタの開発に従事. 正会員.

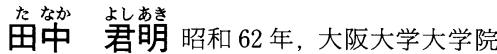
工学研究科修士課程修了。同年, NHK に入 局. 高松放送局を経て, 平成 4 年より，技術 局技術開発センターに勤務. スタジオ昭明設 備, 編集設備の計画, 整備および開発に従 事. 正会員.

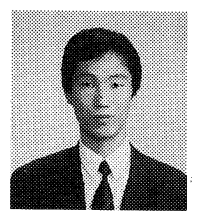

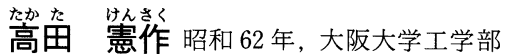
精密工学科卒業. 平成元年, 同大学院博士前 期課程修了。同年，住友電気工業(株)に入 社. 高分子分散型液晶材料の開発に携わる。 現在，同社大阪研究所に勤務。

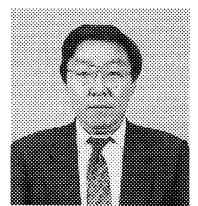

望里野悟昭和 47 年，京都大学工学部 工業化学科卒業. 49 年, 同大学院修士課程 修了。同年，住友電気工業(株) に入社. 平成 4 年より, 高分子分散型液晶, 高分子液晶の 開発に携わる. 現在, 同社大阪研究所主任研 究員.

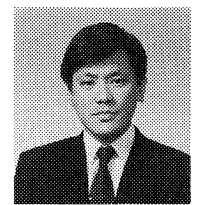

机が架揞る 昭和 55 年, 大阪大学工学部 応用化学科卒業. 昭和 57 年, 同大学院博士 前期課程修了。同年, 住友電気工業 (株) に入 社. 平成元年より, 高分子分散型液晶, 高分 子液晶材料の開発に携わる。現在，同社大阪 研究所に勤務。 